\title{
DNA 親子鑒定的倫理與法律思考:
}

\section{以未成年人權益保護為視角}

\author{
李菊萍
}

\section{摘要}

中國大陸 DNA 親子鑒定機構日益增多, 但缺乏統一標準和 法律監管, 訴訟外個人申請親子鍳定數量攀升, DNA 親子鍳定的 技街分析異化為一些男性 “監妻定子” 的工具, 其結果傷害了無幸 的孩子。分析指出, 僅靠道德約束不能消除 DNA 親子監定機構 間的無序的商業化運作, 從而減少給未成年人造成的傷害。建議 儘快制定“親子監定法”, 確認子女利益最佳原則、親子監定受限 原則和親子關係推定原則, 建立親子監定監管機制、確立親子鑒 定機構的考核標準和 DNA 親子監定的認定標準、嚴格限定親子 監定的範圍和申請人、規定親子鍳定的複檢制度、資料保護和 DNA 鿵私保密制度。

【關鍵詞】 DNA 親子鑒定 倫理 法律 未成年人 權益保護

所謂親子鑒定指的是應用人類生物學、遺傳學的理論和技術， 判定父母與子女之間是否存在親生關係的鑒定。“親子鑒定”的概念

李菊萍, 西北政法大學公安學院講師, 中國西安, 郵編：710063。

《中外醫學哲學》VIII:2 (2010 年) : 頁 87-103。

(C) Copyright 2010 by Global Scholarly Publications. 
早在我國三國時期就已經萌發, 滴血認親, 即 “血相容者為親”。我 國著名的法醫名著《洗冤集錄》也記載了將子女血液滴在父母的屍骨 上以血液能否滲入骨中來認親的案例。姑且不説其方法科學與否, 足以折射出我國人民對“親子” 情有獨鍾。隨著科學發展，人類對 DNA 分析技術的發展, 使得科學的親子鑒定成為可能。現在普遍運 用的是 DNA 多態性分析, 猶如一張 “人體身份證”, 它能準確、客觀 地得出鑒定結果，肯定生物學父子關係的準確率在 $99.99 \%$ 以上，否 定準確率則更高, 幾近 $100 \%$ 。隨著科技的發展和科學水準的提高, 鑒定的物件已不再局限於直系的父母與子女兩代的個體，對隔代、 同胞甚至旁系的個體間是否存在親緣關係也能作出相應的鑒定。

親子鑒定是法醫生物學鑒定的重要內容之一，親子鑒定可以分 為：訴訟內親子鑒定與訴訟外親子鑒定, 訴訟內親子鑒定主要是指 司法活動中由法院委託進行的親子鑒定，訴訟外親子鑒定主要是指 向社會公開的親子鑒定。親子鑒定所涉及的範圍大致有 : 遺產繼承、 丈夫對妻子忠誠的懷疑、移民、懷疑醫院產房錯抱嬰兒、被拐賣兒 童的認領、計劃生育工作的需要、懷疑超生需進行親子鑒定確認、 失散親人的認親、以及在刑事案件中通過親子鑒定認定強姦致孕的 罪犯等。

\section{一、我國 DNA 親子鑒定的現狀分析}

\section{DNA 親子鑒定機構增多, 有商業化運作趨勢}

當代中國的親子鑒定肇始於訴訟內親子鑒定。在 20 世紀末，上 海市高級人民法院就當事人要求作親子鑒定的事宜請示最高人民法 院, 後者以批示的形式准許人民法院在審判工作中採用人類白細胞 抗原作親子鑒定。隨後親子鑒定迅速發展, 短短二十多年間, 便成 立了許多親子鑒定機構, 醫學院校實驗室和許多城市的醫院、血站 也相繼開展了親子鑒定業務。此外, 眾多秘密的 “親子鑒定公司”也

(1) 任學強: 〈論親子鑒定中的未成年人權利保障〉, 《青年研究》, 2007 年, 第 8 期, 頁 $30^{\circ}$ 
如雨後春简，加入到 “市場化競爭” 的行列。更甚者在計程車上隨時 有計程車司機提供的親子鑒定公司的宣傳廣告。記者按照司機提供 的聯繫方式找到該公司，接待人員信誓旦旦廿四小時就可以檢測出 結果, 宣稱國內最低價一一收費只是七百五十元。經過記者暗訪, 結果讓人觸目驚心，不寒而慄：該公司親子鑒定業務沒有獲得批准， 鑒定人員剛到該公司工作不到一個月，且所學的專業並非此類專 業。2

\section{2. 訴訟外親子鑒定數量攀升}

2004 年廣東中山大學醫學院所做的親子鑒定高達一千例；北京 朝陽醫院當年做的親子鑒定亦較往年倍增; 河南省人民醫院六年就為 三千五百個家庭做了親子鑒定。 ${ }^{3}$ 據相關部門統計，我國親子鑒定的 數量正以每年 $20 \%$ 的速度遞增。在浙江和廣東等地, 做鑒定的人數, 正以每年 $40 \%$ 至 $50 \%$ 的速度激增。 4

據廣州醫學院第三附屬醫院 (原市第二人民醫院) 法醫物證司法 鑒定所主任法醫師黎青介紹，該所 1997 年開張之初，前來做鑒定的 人群一般是由司法部門或律師推薦來的居多, 大多與入戶、出入境 需要及遺產判定的法律緣由為主。發展到最近一兩年，個人申請親 子鑒定的正在逐漸增多，時下已經增加到了佔總鑒定人群的 $23 \%$ 左 右的較高比例。5

在個人申請親子鑒定激增趨勢的同時，人們對親子鑒定卻仍舊 盲目信任，甚至有些人產生了依賴情結。據環球時報一一環球網調 查（共約五萬七千票）如何看待親子鑒定，支持者有將近一半！“孩 子是誰的，鑒定很重要”這是多數人的思想。

(2) 潘從武：〈暗訪親子鑒定公司〉, 《百姓生活》, 2009 年, 第 12 期, 頁 13 。

（3）顏志偉：〈我國親子鑒定法律問題再研究〉, 《河南社會科學》, 2008 年, 第 5 期, 真 $73^{\circ}$

（4）鄭篠倩、李承錦、肖樹臣: 〈產前親子監定悄然興起挑戰社會倫理〉, 《工人日報》, 2009 年 9 月 6 日。

(5) 同上。 
如下圖表 :

\begin{tabular}{|l|l|l|l|l|}
\hline 支持 & 反對 & 質疑 & 無語 & 難説 \\
\hline $45.2 \%$ & $5.83 \%$ & $4.84 \%$ & $37.49 \%$ & $6.66 \%$ \\
\hline
\end{tabular}

\section{3. 我國對親子鑒定實驗室尚無統一認證標準, 對鑒定機構缺乏 應有的監管。}

鑒定的市場化開展, 惡性競爭、商業氣味濃烈。我國還沒有專 門法律規定親子鑒定問題, 親子鑒定作為一項有關於婚姻關係、家 庭關係的技術活動，在從司法活動（訴訟內鑒定）延伸至訴訟外鑒定 的過程中，市場化和商業化異化了該活動的技術性。當親子鑒定向 社會開放後, 有關鑒定機構無資質、鑒定人員無資格、鑒定程式不 規範和鑒定行為走過程等事件被大量報導。6

\section{二、我國 DNA 親子鑒定中的倫理學問題}

親子鑒定的商業化和無序化運作, 表面上 “繁榮”了親子鑒定市 場。但是, 人們或有意無意地忽視了親子鑒定的倫理道德問題, 對 其增添了社會的不和諧因素沒予足夠的重視。親子鑒定, 滿足了父 或母的知情權, 卻漠視了 “子”的權利, 離散了許多原本幸福的家庭, 傷害了無啈的孩子。從著重保護孩子的權利特別是未成年孩子的視 角出發來審視我國的親子鑒定所存在的倫理問題 :

\section{1. 親子鑒定成為“傷子鑒定”}

親子鑒定解決了諸多刑事和民事難題, 但對於處於弱勢群體的 未成年人來説是最大的受害者。未成年人因其年幼, 身體和智力尚 處於發育階段, 心理因素不穩定, 認知能力低下, 處於弱勢地位, 其權利容易受到漠視和侵犯。

（6）曾令健：〈在親子鑒定和寬容精神之間〉, 《法律與生活》, 2009 年, 第 15 期, 頁 31 。 
我國有“棒子底下出孝子”、“玉不㻟, 不成器”的傳統觀念, 忽 視未成年人獨立人格和主體意識。在親子箽定中，未成年人的隱私 權、名譽權、經濟權往往沒有得到考慮。父母為了自己的利益, 可 以隨意決定或拒絕作親子鑒定，在鑒定中忽略未成年人的尊嚴，嚴 重損害未成年人的利益。

諸多案例顯示，原本開朗、可愛的孩子因為做了親子鑒定，變

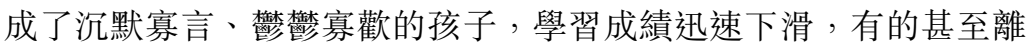
家出走, 更有甚者以結束自己生命為結局。有人戲稱親子鑒定實際是 “傷子鑒定”。7

\section{2. 親子鍳定成為男性選擇性承擔父親義務的“工具”}

從性別視角看, 男性提出親子鑒定的數量遠大於女性。據調查, 在深圳個人委託作親子鑒定的家庭， $75 \%$ 是由丈夫提出來的， ${ }^{8}$ 有確 鉢證據證明妻子有婚外性行為的很少, 大部分人作親子鑒定的理由 是無端猜疑。其一，男方發現妻子有“第三者”，懷疑子女不是其所 生，為排除子女是否為其所生的這一 “心病”，要求鑒定。其二，在 夫妻離婚時，丈夫懷疑小孩不是其親生，為了對以前撫養小孩的費 用和精神損失要求妻子賠償，提出申請鑒定。其三，丈夫懷疑 “小孩 長得不像我”、“孩子的血型與我不一樣”、“小孩是我們分居兩地時 懷上的”等藉口，決定作親子鑒定。其四，未婚男女婚前同居或發生 性關係，女方懷孕生下子女後，要求男方承擔撫養費，男方懷疑自 己的父親身份，不願承擔撫養費，要求作親子鑒定。

根據我國《婚姻法》的規定，子女包括婚生子女和非婚生子女。 如果説非婚生子女的誕生是一種錯, 錯也在父母, 與孩子毫無關係。 而由親子鑒定出的非婚生的孩子，一般被當作“野種”趕出原來家庭

（7）關於親子鑒定傷害孩子的案例報導不勝枚舉, 其中 2007 年深圳發生了一宗丈夫得 知親子鑒定結果後, 從妻子手中抱過嬰兒, 舉起嬰兒並摔向水泥地面, 致孩子死 亡的案例, 令人觸目驚心。參鄭巧: 〈親子鑒定下的父愛變異〉, 《生活與法律》, 2009 年, 第 15 期, 頁 30 。

（8）任學強：〈論親子鑒定中的未成年人權利保障〉, 《青年研究》, 2007 年, 第 8 期, 頁 31 。 
或作為私生子而俳徊在社會的邊緣。實際上就把父母之錯歸各於孩 子, 孩了因此受到無辜的傷害。非婚生的孩子在中國這樣歷史傳統 和世俗文化所營造的倫理氛圍中名譽權會受到嚴重的侵害，對孩子 今後的健康成長極為不利。在婚姻關係中, 因為丈夫懷疑妻子的忠 貞而提出親子箽定, 即使結果為親生子女, 也會導致夫妻感情破裂 甚至離婚, 外人也會對孩子的身份產生猜忌和傳言, 會在孩子的心 靈投下陰影。學界有人就此提出在解決婚姻和家庭的問題上不應唯 夫妻感情是從, 需要推崇 “孩子至上” 的觀念。9 在解決婚姻危機的 親子鑒定上，應該首先考慮孩子的正當權益及以後的健康成長。

親子鑒定業務的迅速發展從一個側面反映出當前社會家庭關係 的不穩定，很多家庭存在著信任危機。丈夫提出親子鑒定無疑是出 於對妻子的不信任, 在這種情況下, 妻子無論是為了表明自己的清 白還是出於無奈, 都會 “配合” 丈夫的要求去做鑒定; 在丈夫瞞著妻 子私自進行鑒定的情況下, 從表面上看似不會傷害到妻子的自尊, 即使將來鑒定結果孩子是其親生, 消除的也只是已存的疑慮, 但先 前夫妻間的信任很難恢復, 因為 “很難相信, 一種欺騙的行為一目 的是為了獲取欺騙的證據一一能提供一種新的信任關係的基礎。” 10

但原有的信任也會隨之蕩然無存。如果親子鑒定動機是維護婚 姻的性倫理和血緣倫理，其結果勢必會造成婚姻和家庭信任危機， 影響到親子關係的穩定。有研究者指出, 親子鑒定雖然能夠使家庭 血緣關係明晰, 但無論丈夫和孩子是否存在親權關係, 其結果都易 於導致感情破裂、家庭破碎。大量的事實也證明，在被鑒定的案例 中只有近 10\%屬於非婚子女, 但因親子鑒定而導致夫妻感情破裂直至 離婚的卻遠遠超過 $10 \%$ 。 ${ }^{11}$ 家庭的破裂, 使未成年人失去社會化的初 始地, 為他們步入成人社會帶來困難, 也會給他們未來的正常生活

(9) 錢廣榮: 〈親子鑒定: 科技維護家庭倫理存在的道德悖論〉, 《倫理學研究》, 2006 年, 第 4 期, 頁 102 。

(10) Gilding, Michael, "DNA Paternity Testing without the Knowledge or Consent of the Mother,” Family Matters No.68 (Winter 2004): 68-75.

(11) 同注 9 。 
埋下陰影。筆者認為, 無論婚姻內還是婚姻外的性關係, 孩子都是 無辜的, 不應成為任何人選擇的對象。應建立一個完善的婚生子女 推定制度, 能用推定方法判㫁出的, 原則上不進行鑒定, 以利於維 護婚姻的穩定、夫妻雙方的尊嚴和孩子的權益。

\section{3. 親子鑒定挑戰家庭倫理觀}

親子鑒定從小的方面説是個人的事，是一個家庭的事，但從整 個社會來看, 則是一個社會倫理問題。因為, 過多男性選擇性地申 請親子鑒定，勢必會選擇性地拋棄他們不願接納的子女以及子女的 母親, 瓦解原本的核心家庭, 導致更多單親家庭的衍生。親子鑒定 的相對確定性, 會觸發家庭的悲劇和人倫關係的緊張。親子鑒定誇 大了血緣因素在父母與子女關係中的作用, 在一定程度上淡化了感 情、責任等因素的重要性。親子鑒定擴大了生理性交往在性愛關係 中的意義，有可能導致婚姻和家庭的信任危機。

人類的性愛關係不僅僅是生理上的自然關係，它更多的卻是社 會行為基礎上的情感關係。因此其作用只限於判別人的自然特徵的 親子鑒定, 有時不僅不能直接解決人們之間的社會和感情問題, 反 而會給社會、人的情感以及與此有關的倫理道德帶來種種問題。親 子鑒定強化性關係的專一性, 忽視了家庭關係中已經存在的社會倫 理。在性愛中, 生理性交具有十分重要的意義, 但是若把生理性交 視為性愛的唯一內容, 則意味著把性愛簡單地理解為與動物交配行 為相似的生命延續現象。父母與子女的關係從根本的意義上是一種 社會關係, 自然的血緣關係只是這種社會關係的基礎, 社會關係並 不能完全還原為自然的血緣關係。社會上有許多動人的故事, 説明 沒有血緣關係的“父母”與“兒女”可以組成令人羡慕的歡樂家庭, 表 現出崇高的家庭道德風範。事實上，在父母和兒女的關係中，感情 的因素起著非常重要的作用, 隨著感情的發展, 自然的血緣關係往 往退至非重要的地位, 這也正是人的社會性的重要體現, 體現了為 人的崇高性。所以, 親子鑒定只是解決了人倫關係中最初級的自然 
方面, 而不能解決甚至是在毀壞著其他方面。親子鑒定事實上放大 了生理性交的地位。12

\section{三、DNA 親子鑒定的法律規制思考}

親子鑒定應用中的中西方的價值理念和法律選擇不同。由於親 子鑒定關涉到假定父親、生父、母親和孩子這些角色，當假定父親 的知情權與相關的經濟利益、母親的隱私權及尊嚴、孩子的利益、 家庭的穩定性不可協調時, 美國是以子女最佳利益至上。而中國多 不關心孩子的利益，只顧成年人，尤其是父親的利益。中國家庭中 的血緣思想是婚生事實確定親子關係的思想根源; 個人懷疑、社會 輿論及家庭成員的壓力型的親子鑒定，極須規範。 ${ }^{13}$

我國親子鑒定中存在的社會倫理問題，僅靠道德教化不足以解 決；無序的競爭、混亂的管理，唯有通過法律規制，才能給親子鑒 定確立法律意義上的資格與標準，強化鑒定人的義務與責任，限制 申請人的資格與範圍, 從而有力地保護家庭關係的穩定, 保護未成 年子女的權益。

從法理上説, 親子關係屬於親屬法律關係, 而我國還沒有單行 的《親屬法》。現有的《民法通則》、《婚姻法》、《繼承法》也沒有規 定親子鑒定問題。在《未成年人保護法》也沒有涉及親子鑒定中的未 成年人的利益保護問題。1 1987 年最高人民法院《關於人民法院在審 判工作中能否採用人類白細胞抗原作親子鑒定問題的批復》, 是我國 現有的關涉親子鑒定問題的“準法律”。該批復規定：對於雙方當事 人同意作親子鑒定的, 一般應予准許; 一方當事人要求作親子鑒定 的，或者子女已超過二周歲的，應視具體情況，從嚴掌握，對其中 必須作親子鑒定的，也要做好當事人及有關人員的思想工作。此條 法律規定至少存在以下缺陷：其一，“應視具體情況，從嚴掌握”的

(12) 薛妙勤：〈對親子鑒定的倫理思考〉, 《科教文匯》, 2008 年, 第 17 期, 頁 199 。

(13) 王延光: 〈中國遺傳倫理研究十年回顧〉, 《中國醫學倫理學》, 2007 年 10 月, 第 20 卷, 第 5 期 , 頁 3-8。 
表述模糊，對於哪些是必要或非必要作親子鑒定的情況，沒有明確 説明，留有較大的解釋空間；其二，鑒定程式中沒有提及對未成年 人的隱私權、名譽權等權利的保障問題; 其三, 此規定距今已有二 十年歷史，人們的婚姻家庭觀念、未成年人權利觀都發生了很大的 變化, 原有的規定已遠遠不能滿足當今社會的要求。因此, 為了有 效地保護未成年人的人身權、經濟權、生命權，應儘快制定 “親子鑒 定法”。本文認為，我國的“親子鑒定法”應當包括以下的原則和制 度：

\section{1. 子女最佳利益原則}

子女最佳利益原則最早是由 1959年《兒童權利宣言》為保護未成 年人權利所確認的一項國際性指導原則。此後, 若干國際公約和區 域性條款又多次被重申。如《兒童權利公約》( 以下簡稱《公約》) 第 三條第一款 “關於未成年人的一切行為, 無論是由公私社會福利機 構、法院、行政當局或立法機構執行，均應以未成年人的最大利益 為首要考慮。”《公約》第二十七條第一款規定 “締約國確認每個兒童 享有以促進其生理、心理、精神、道德和社會發展的生活水準。”《公 約》第二十七條第二款規定 “父母或其他負責照顧兒童的人，負有在 其能力和經濟條件許可的範圍內, 確保兒童發展所需生活條件的首 要責任。”在普通法系的英國、美國、澳州、加拿大在立法實踐中， 直接在法律中體現了這一原則，大陸法系的德國、意大利、法國等 也在立法中體現著這一原則。14 我國《婚姻法》規定了非婚生子女與 婚生子女有相同的權利。我國《未成年人保護法》第三條第一款規定 “未成年人享有生存權、發展權、受保護權、參與權等權利，國家 根據未成年人身心發展特點給予特殊、優先保護，保障未成年人的 合法權益不受侵犯。”也確立了最大程度保護未成年人利益的原則。

(14) 陳葦、謝京傑：〈論“兒童最大利益優先原則”在我國的確立一一兼論《婚姻法》 等相關法律的不足及其完善〉, 《法商研究》, 2005 年, 第 5 期, 頁 39-45。 
因此, 應當將子女最佳利益原則作為規範親子箽定法律制度的最基 本原則。

子女最佳利益原則非常靈活, 因為至今沒有任何國際檔對 “子女 最佳利益”的內涵和外延加以界定，不同的人總是根據不同的背景、 不同的個體權利以及不同的國家義務對 “最大利益”賦予不同的含 義。 ${ }^{15}$ 各國親子法有不同的發展程度, 但一般也是從父權主義進展至 父母權利平等原則, 再發展至子女最佳利益原則 (the best interests of the child) 。2 0 世紀中期後, 家庭法深受福利國家之介入主義 (Interventionism) 的影響, 呈現 “私法公法化” 或 “身份法公法化” 的趨 勢, 國家通過立法及司法介入親子關係領域, 以維護弱勢子女權益, 而子女最佳利益原則的確立, 則為國家介入親子關係時的最高指導 原則及具體審酌標準。該原則已在英美法系和大陸法系國家發展成 法院在處理父母離婚後子女監護案件時的最高準則。“子女最佳利 益”, 不僅要考慮過去已經發生的和現在正在發生的事實, 還必須預 測將來可能發生的事實等諸多因素。16 從這可以看出 “子女最佳利 益”原則成為各國處理親子法律關係的最高指導原則之一。

筆者主張我國制定 “親子鑒定法” 時應引進 “子女最佳利益” 原 則, 以“子女最佳利益”為最高指導原則, 摒棄父母權利本位思想, 將 “子女最佳利益” 置於父母的知情權之上, 從而有效保護未成年人 的權利。

\section{2. 親子鍳定啟動受限原則}

在西方, 親子鑒定的主要目的主要用於法庭判定財產繼承或爭 取孩子的撫養費, 很少人用親子鑒定來檢驗妻子的忠貞和孩子的親 疏。而我國大多數申請親子鑒定的男子實際上是 “鑒妻定子”，一般 具有否定父子關係和對妻子的忠貞猜忌之意圖。要麼, 是男子與其

(15) 王雪梅：〈兒童權利保護的“最大利益原則”研究(下)〉, 《環球法律評論》, 2003 年, 第 1 期, 頁 109-111。

(16) 陳葦、王鿂：〈澳大利亞兒童權益保護立法評價及其對我國立法的啟示一一以家 庭法和子女撫養 (評估) 法為研究物件〉, 《甘肅政法學院學報》, 2007 年, 第 3 期, 頁 15 。 
他女子發生了婚外性關係, 為了甄別、選擇是否要承擔非婚生的孩 子撫養義務。

為了“鑒妻定子”而啟動鑒定程式，凸現了嚴重的男權思想和所 謂的骨血意識。受幾千年來的夫權為綱思想的影響, 有些人 “大男人” 主義思想嚴重, 往往認為自己是家庭的主宰, 妻子應該無條件服從, 絕不能容忍妻子對他不忠。在傳統男權思想根深蒂固的心理作用 下，道德倫理危機和信任危機使男性不安全感劇增，大部分妻子在 被逼無奈之下進行親子鑒定, 目的只是為了還自己一個清白, 或給 孩子爭取撫養權和繼承權。這種以男權力量為主宰的鑒定在某種程 度上便是 “大男子”主義在作崇, 其骨子裏是男權至上觀念的表露。

任由個人啟動親子鑒定程式，魯莽、輕率進行親子鑒定，不僅 白白浪費時間、精力和金錢, 而且會使更多的家庭因鑒定而引起矛 盾、加劇夫妻和伴侣的感情危機、導致更多的家庭因孩子血緣問題 而解體，使無辜的孩子面臨親情危機。更甚者，還可能因鑒定結論 而引發自殺、孩子被拋棄、被殺害等。

根據美國法律，法院可以根據一方當事人的請求，要求子女、 父母或被指認為生父者提供血親鑒定結果, 以確定生父。17《法國民 法典》第十六條規定, 實施 DNA 箽定, 應限於裁判程式中緊急調查、 證據調查、科學研究和醫學上之目的。看來, 親子鑒定, 應當受到 目的限制。從國外立法經驗來看, 親子鑒定在訴訟中的提出一般僅 限於婚生否認之訴、認領之訴及其必要的場合，其主要考慮非婚生 未成年人子女的利益考慮。認領之訴過程中親子鑒定的提出, 首先 可以滿足未成年人子女的物質搤養條件, 解決其生存、發展的困惑。

在另一方面, 與一般的司法鑒定不同, 親子鑒定涉及父親、母 親和未成年子女三方利益, 未成年子女行為能力不完備, 不能正確 表達自己的意思，由父或母提出親子鑒定，都忽視了未成年子女的 權益保護。即使由母親一方作為法定代理人, 由於利害關係, 有時 不能兼顧自己與孩子兩方面利益。正是因為法律沒有將個人排除親

(17) 夏吟蘭：《美國現代婚姻家庭制度》(北京：中國政法大學出版社, 1999), 頁 96 。 
子鑒定委託人範圍, 個人可以任意委託親子鑒定, 加上親子鑒定機 構管理的缺失, 造成了或真或假的親子鑒定結論猶如一個重磅炸彈 到處橫飛的混亂局面。因此, 親子鑒定的委託人以僅限於法院為宜。 這樣的規定, 可以保證親子鑒定的必要性、正當性及其高度專業性 的分析品質，體現對個人隱私尊重，防止親子鑒定被監用。18

當然, 絕對地限制個人啟動親子鑒定程式, 可能會受到 “如何體 現當事人的私權自治的質疑” ? 但是, 從未成年人利益保護之角度來 考量, 限制的利大於弊。況且, 當事人的意志本身就是法院啟動親 子鑒定程式的原發私人意思, 其意思並沒有受到限制。相反, 倒是 如今徒增的非訴訟的親子鑒定程式的啟動, 由於沒有法律規範、沒 有監管而有所氾監。考慮到前述男權主義封建意識下, 男子申請親 子鑒定高比例的社會事實, 最起碼應當限制男性是為了檢驗妻子的 忠貞、為了逃避婚姻關係中對子女的撫養義務而申請的親子鑒定。

\section{3. 親子關係推定原則}

親子關係推定是指在具備法定條件的情形下, 某子女被法律推 定為某男子的子女的法律制度, 從而使子女的法律身份處於穩定的 狀態, 有效地維護子女的利益。在丈夫否認子女為婚生子女之訴中, 只有丈夫提出具體證據證明其妻子受孕期間與其他男子發生了性關 係, 或者其本身不具有生育能力等, 才可以否定親子的推定。美國 最高法院從未成年人最大利益原則出發, 如果親子鑒定對子女不 利，或子女不願知曉結果，即使婚生親子間雖無血緣關係，但具有 親子生活的事實和意思, 表現出父母合適地履行了父母的責任, 在 法律上維護該婚生子女的地位, 不得變更。19 在法國, 存在親子共 同生活的時間或事實, 親子關係不論有無血緣關係也因而確定, 不 能加以爭執, 自然也無親子鑒定適用的餘地, 其他國家也有類似的

(18) 鮑紅香：〈子女最佳利益原則對親子鑒定程式啟動的限制〉, 《懷化學院學報》, 2009 年, 第 12 期, 頁 44 。

(19) 鄧學仁等：《DNA 鑒定——親子關係爭端之解決》(台北: 元照出版公司, 2007), 頁 106 。 
規定。應建立一個完善的婚生子女推定制度, 能用推定方法判斷出 的，原則上不進行鑒定，以利於維護婚姻的穩定、夫妻雙方的尊嚴 和孩子的權益。

根據醫學知識，結合外國立法經驗，我國的親子關係推定原則 的內容應當包括：

（1）如果子女是母親在婚姻關係存續期間受胎出生,則推母親的 丈夫為該子女的生父; 如果子女是在母親婚姻解除十月內出生, 則 應推定母親的原丈夫為該子女的生父; 如果母親的丈夫被判決宣告 失蹤或宣告死亡的情況下, 子女於三百天之後出生, 則不能推定丈 夫為該子女的父親。

(2) 如果子女是在母親與人非法同居期間受胎或出生的, 則推定 與該子女的母親非法同居的男子為其生父。

(3) 如果母親再婚或因母親先後與不同的男子非法同居, 而致使 數名男子均可能為子女的生父時，依下列規則處理：其一，在母親 的丈夫和與母親非法同居的男子之間, 應優先推定母親的丈夫為子 女的生父; 其二, 在子女出生時母親的丈夫和受胎時母親的丈夫之 間，應優先推定子女出生時母親的丈夫為該子女的生父; 其三，在 子女出生時與母親非法同居的男子和受胎時與母親非法同居的男子 之間，應優先推定子女出生時與母親非法同居的男子為該子女的生 父。

同時規定在子女出生的前第三百天到第一百八十天之間不可能 與子女的母親有性關係, 或者自己沒生育能力的特定情況下, 可以 否定推定。

\section{4. 親子鑒定法應包括的制度}

(1) 建立親子鑒定監管機制：國外開展親子鑒定一般由衞生行政 部門統一管理，管理部門在對鑒定機構考核檢查後發放許可證，並 定期進行抽檢。如美國 DNA 分析方法技術工作組提出了 “法醫 DNA 分型標準化方案和品質控制指南”; 國際法醫血液遺傳學會提出了 “DNA分型技術建議”; 美國血庫協會的親子鑒定技術標準和病理學 
家協會提出了親子鑒定熟練性程度的方案等。

目前在我國實行鑒定行為的機構和從業人員比較混亂，以致在 市場上、互聯網上我們可以隨處可看見親子鑒定的廣告；沒有統一 的鑒定程式、方法及材料和結果，使鑒定品質存在得不到保障的隱 患。鑒於此, 我國應儘快確立親子鑒定資格認定的行業規範和相關 的法律法規，使經營者有法可依，依法進行親子鑒定的有關行為。

(2) 嚴格限定親子鑒定範圍, 包括對鑒定申請人的限制：親子鑒 定是一項科學性、技術性、倫理學和實踐性極強的工作, 不能把它 視為一種普通的醫療服務甚至社會服務來對待, 應糾正觀念 : 在無 法可依的無序鑒定狀態，對他進行必要的限制和管理，對親子鑒定 的使用應當採取謹慎的態度。對於訴訟外的親子鑒定, 由夫妻雙方 共同提起, 經省級親子鑒定管理機構批准後, 向鑒定機構提出。沒 有管理機構的批准, 鑒定機構不能隨意啟動鑒定程式。省級管理機 構組成的人員應該包括親子鑒定專家、法律工作者以及司法行政部 門的工作人員，負責本地親子鑒定工作的批准、認定和指導。對於 訴訟內的親子鑒定, 由當事人一方或雙方提出申請, 法院批准後, 提交鑒定機構鑒定。沒有法院的批准或委託, 鑒定機構不得啟動鑒 定程式; 否則, 不具有證據效力, 不能進入訴訟程式。

(3) 鑒定機構考核標準 : 鑒定機構的設備設施、技術條件及其人 員的素質條件等作出法律意義上的規定。親子鑒定機構應有明確的 業務範圍, 必要的儀器設備, 標準化的檢測實驗室, 符合條件的專 業鑒定人員。如規定鑒定人員必須具有本專業的高級職稱、五年的 相關工作經歷、本科以上的學歷、及具有本專業的執業資格。另外 應排除受過刑事處罰、開除公職及被撤銷親子鑒定資格的人員從事 親子鑒定業務。嚴格鑒定有關機構及鑒定人員的入門條件，以杜絕 某些不具備資格的單位為了“創收”，而從事親子鑒定業務。確立親 子鑒定專業技術人員的繼續教育義務; 規定錯誤鑒定的法律責任和 賠償範圍。 
(4) 確立親子關係的認定標準：以國際上通行的親子關係概率為 大於 99.73\% 作為認定事實血緣關係的最低標準。結果低於此標準應 增加遺傳基因座的檢驗數目，以提高親子關係概率。確立親子鑒定 技術規範，包括用於親子鑒定必須檢驗的遺傳基因座目錄，推薦基 因座目錄以及相應的基因頻率資料庫。檢驗樣本一式多份，分別交 給多個檢驗小組，結果一致，才可得出檢驗結論。

(5) 規定鑒定報告前的覆核制度 : 如果當事人對結果有異議, 有 權要求複檢, 批准機關應交其他鑒定機構或原鑒定機構其他鑒定人 員, 重新鑒定, 該複檢為終局結論。若經複檢原鑒定無誤，複檢人 署名; 若複驗發現原鑒定結論有誤，應提出新的鑒定結論，原鑒定 結論作廢。

(6) 建立鑒定資料的保護和DNA隱私保密制度: 對於鑒定機構來 説, 申請鑒定人的姓名、血液樣本、申請手續證明書等資料, 要做 好妥善保護, 不得對外洩露。個人 DNA 遺傳基因資訊，屬於其個人 隱私，應當嚴格保密，不得擅自洩露、不得應用於親子鑒定以外的 事項——哪怕是以科研的名義。對於 DNA 鑒定結果，除當事人、法 院可以知道外, 應當嚴格保密, 鑒定機構不得對外界公佈。當事人, 尤其是男方當事人不得把非親生的鑒定結果對外散佈，洩露未成年 人的隱私。法院在審理此項內容時, 一定要秘密進行, 不得公開, 切實維護未成年人的權利。

\section{四、結束語}

孩子是維繫父母關係的紐帶, 親子鑒定在一定意義上, 是自私 自利的父母 (尤其是父親) 刺向孩子心靈的一把利刃，也是產生社會 不和諧的可能因素。因此，從保護未成年人的視角來看，親子鑒定 無論是從倫理道德上加以約束, 還是從法律上加以規制都是必要的。

未成年人是人類的未來, 未成年人現在的幸福就是人類未來的 幸福, 未成年人的生存和發展既有賴於現實社會的文明和進步, 又 是未來社會文明與進步的希望所在，保護未成年人現在的權利也是 
在保護人類自己的未來。誠如梁啟超於《少年中國説》所言 : “少年 智則國智，少年富則國富，少年強則國強，少年獨立則國獨立…… 少年進步則國進步, 少年勝於歐洲, 則國勝於歐洲, 少年雄於地球, 則國雄於地球。” 20 


\section{參考文獻}

王延光：〈中國遺傳倫理研究十年回顧〉, 《中國醫學倫理學》, 2007 年 10 月，第 20 卷，第 5 期，頁 3-8。

王雪梅：〈兒童權利保護的“最大利益原則”研究(下)〉, 《環球法律評論》, 2003 年, 第 1 期, 頁 108-119。

任學強：〈論親子鑒定中的未成年人權利保障〉, 《青年研究》, 2007 年, 第 8 期, 頁 30-36。

季羡林編：《學者小品經典 (第 1 輯)》, 長沙 : 新世紀, 1998 。

夏吟蘭：《美國現代婚姻家庭制度》, 北京：中國政法大學出版社, 1999 。 恩格爾哈特 (H. Tristram Engelhardt, Jr.) 著, 范瑞平譯：《生命倫理學基礎》, 北京：北京大學出版社，2006 年。

陳 莘、王 鿂：〈澳大利亞兒童權益保護立法評價及其對我國立法的啟 示——以家庭法和子女撫養(評估)法為研究物件〉, 《甘肅政法學院學 報》, 2001 年, 第 3 期, 頁 10-18。

陳 葦、謝京傑：〈論“兒童最大利益優先原則”在我國的確立一一兼論《婚 姻法》等相關法律的不足及其完善〉, 《法商研究》, 2005 年, 第 5 期, 頁 39-45。

曾令健：〈在親子鑒定和寬容精神之間〉, 《法律與生活》, 2009 年, 第 15 期，頁 31 。

潘從武：〈暗訪親子鑒定公司〉, 《百姓生活》, 2009 年, 第 12 期, 頁 $12-13$ 。 鄭巧：〈親子鑒定下的父愛變異〉, 《生活與法律》, 2009 年, 第 15 期, 頁 30 。

鄭篠倩、李承錦、肖樹臣：〈產前親子鑒定悄然興起挑戰社會倫理〉, 《工人 日報》, 2009 年 9 月 6 日。

鄧學仁等：《DNA 擥定一一親子關係爭端之解決》, 台北：元照出版公司, 2007 。

錢廣榮: 〈親子鑒定: 科技維護家庭倫理存在的道德悖論〉, 《倫理學研究》, 2006 年，第 4 期，頁 100-103。

鮑紅香：〈子女最佳利益原則對親子鑒定程式啟動的限制〉, 《懷化學院學 報》, 2009 年, 第 12 期, 頁 42-44。

薛妙勤：〈對親子鑒定的倫理思考〉, 《科教文匯》, 2008 年, 第 17 期, 頁 199 。

顏志偉：〈我國親子鑒定法律問題再研究〉, 《河南社會科學》, 2008 年, 第 5 期 , 頁 72-75。

Gilding, Michael, "DNA Paternity Testing without the Knowledge or Consent of the Mother,” Family Matters No.68 (Winter 2004): 68-75. 